\title{
Effect of the activity of the Brazilian polyherbal formulation: Eucalyptus globulus Labill, Peltodon radicans Pohl and Schinus terebinthifolius Radd in inflammatory models
}

\author{
Karina C.P. Medeiros ${ }^{1}$, Juliana C. Monteiro ${ }^{1}$, Margareth F.F.M. Diniz, Isac A. Medeiros ${ }^{1}$, \\ Bagnólia. A. Silva ${ }^{1}$, Márcia R. Piuvezam ${ }^{1,2 *}$ \\ ${ }^{1}$ Laboratório de Tecnologia Farmacêutica Prof. Delby F. de Medeiros, Universidade Federal da Paraíba, Caixa \\ Postal 5009, 58051-970, João Pessoa, PB, Brazil, \\ ${ }^{2}$ Departamento de Fisiologia e Patologia, Universidade Federal da Paraíba, 58051-970, João Pessoa, PB, Brazil
}

\begin{abstract}
RESUMO: O medicamento fitoterápico brasileiro - BPF é composto de corantes das plantas Eucalyptus globulus Labill, Peltodon radicans Pohl e Schinus terebinthifolius Raddi em alcool a $13,3^{\circ} \mathrm{GL}$. Este medicamento é popularmente usado no estado da Paraíba, Brasil desde 1889 como anti-séptico e antiinflamatório. $\mathrm{O}$ objetivo deste estudo foi avaliar a propriedade antiinflamatória deste medicamento fitoterápico. Para tal, foram utilizadas as técnicas de edema de orelha em camundongos induzido por 12-O-tetradecanoilforbol 13-acetato (TPA) ou capsaicina e o edema de pata de rato induzido por carragenina. O BPF na dose de $26 \mathrm{~mL} / \mathrm{kg}$ inibiu tanto edema de orelha induzido por TPA como por capsaicina a $49 \%(\mathrm{p}<0.05)$ e $24 \%(\mathrm{p}<0.01)$ respectivamente. Estudos preliminares utilizando a técnica de edema de pata induzido por carragenina demonstraram que a administração oral também inibiu o edema de pata em aproximadamente $29 \%$. Os resultados demonstraram que o medicamento fitoterápico brasileiro (BPF) apresentou propriedades antiinflamatórias e a melhor dose foi aquela que é usada pela população.
\end{abstract}

Unitermos: Medicamento fitoterápico brasileiro, atividade antiinflamatória, capsaicina, 12-Otetradecanoilforbol 13-acetato.

\begin{abstract}
The Brazilian polyherbal formulation (BPF) is composed by dyes of Eucalyptus globulus Labill, Peltodon radicans Pohl and Schinus terebinthifolius Raddi in alcohol at $13.3^{\circ} \mathrm{GL}$. The formulation is popularly used in Paraíba state, Brazil since 1889 and it is used as an antiseptic and anti-inflammatory medicine. The aim of this study was to evaluate the anti-inflammatory property of the polyherbal formulation. For this purpose it was used the12-O-tetradecanoylphorbol 13 -acetate (TPA) and capsaicin-induced mouse ear edema and the carrageenan-induced rat paw edema. The BPF at dose of $26 \mathrm{~mL} / \mathrm{Kg}$ inhibited both 12-O-tetradecanoylphorbol 13-acetate (TPA) and capsaicin-induced ear edema by $49 \%(\mathrm{p}<0.05)$ and $24 \%(\mathrm{p}<0.01)$ respectively. Preliminary results on carrageenan-induced rat paw edema demonstrated that oral administration also inhibited the paw edema by approximately $29 \%$. The results demonstrate that the Brazilian polyherbal formulation has anti-inflammatory activity and the better dose was the one used by the population.
\end{abstract}

Keywords: Brazilian polyherbal formulation, anti-inflammatory activity, capsaicin, 12-Otetradecanoylphorbol 13-acetate.

\section{INRODUCTION}

The Brazilian polyherbal formulation (BPF) is popularly used in Paraíba state since 1889 besides Rio Grande do Norte, Pernambuco and Ceará states, Brazil. The BPF is used for the treatment of several diseases such as wounds (internal or external), tonsillitis, laryngitis, bites of insects, spines, furuncles, varicose ulcer, sun burns, nasal hemorrhages, rhinitis, skin cleaning, besides stomach and intestinal problems (www.aguarabelo.com. br). The BPF is presented as a hydrolyte form and it is composed with dyes from three Northeastern plants such as: Eucalyptus globulus Labill, Peltodon radicans Pohl and Schinus terebinthifolius Raddi popularly known as "eucalipto", "hortelã da folha graúda" and "aroeira da praia" respectively (Matos, 1999).

Eucalyptus globulus Labill has analgesic, anti-inflammatory (Silva et al., 2003; Lu et al., 2004) antioxidant (Grassmann et al., 2000) and antipyretic effects. The plant has inhibitory effect on the production of tumor necrosis factor $\alpha$ (TNF- $\alpha$ ), interleukin $1 \beta$ (IL$1 \beta$ ) leukotriene B4 and thromboxane B2 by inflammatory cells (Juergens et al., 1998a). Eucalyptus globulus and Peltodon radicans Pohl are used for the treatment of respiratory infections, such as cold, flu and sinus congestion (Tavares et al., 2006). Peltodon radicans Pohl has also anti-inflammatory and anti-helminthic activities (Rodriguez; Carvalho, 2001). The other plant present 
on the BPF is the Schinus terebinthifolius Raddi and has antiseptic, anti-inflammatory, balsamic, haemostatic activities. This plant is commonly used for the treatment of wounds and urinary and respiratory infections (Braga, 1953; Delorne; Miola, 1989 and Melo Junior et al., 2002). The importance of these plants has promoted their inclusion in Brazilian Pharmacopoeia (Brandão et al., 2006).

Although each of these plants has been studied separately, all of them demonstrated anti-inflammatory and antiseptic activities. The polyherbal formulation was not scientific validate yet.

The goal of the present study was to validate scientifically the BPF using the inflammatory experimental models.

\section{MATERIAL AND METHODS}

Peltodon radicans Pohl and Schinus terebinthifolius Raddi had been collected in Bananeiras, and Cabedelo, state PB, respectively. The plant parts used for the polyherbal formulation (BPF) are the essential oil of the Eucalyptus globulus (Glamir, São Paulo, Brazil) and the leaves and shaft of the Peltodon radicans Pohl and Schinus terebinthifolius Raddi.

Polyherbal Formulation

The formulation was prepared to $5 \mathrm{~mL}$ :

Eucalyptus globulus Labill hydrolate.... $.0 .6 \mathrm{~mL}$ Peltodon radicans Pohl hydrolate $2.2 \mathrm{~mL}$ Schinus terebinthifolius hydrolate. $.2 .2 \mathrm{~mL}$

\section{Drugs and chemicals}

The following drugs and chemicals were used: 12-O-tetradecanoylphorbol 13-acetate (TPA), capsaicin, carrageenan, and $\mathrm{NaCl}$ were purchased from Sigma Chemical Co. (St Louis, MO), alcohol was purchased from Merck KaGA (Darmstadt, Germany), dexamethasone and indomethacin were purchased from BDH (UK).

\section{Animals}

Male Wistar rats (150-250 g) and male Swiss mice (20-30 g) were used throughout the experiments. The animals were supplied by the Animal Facility from the Laboratório de Tecnologia Farmacêutica Delby Fernandes Medeiros (Universidade Federal da Paraíba). All experiments were carried out with strict adherence to ethical guidelines (Sherwin et al., 2003). The control animal group received the vehicle (alcohol to $13.3 \mathrm{rd}$ GL). The oral rout was used to treat the animals with the polyherbal formulation.

\section{Models of inflammation}

12-O-tetradecanoylphorbol 13-acetate

(TPA) capsaicin-induced mouse ear edema
Edema was induced according to the method described by Merlos et al. (1991) and Mantione and Rodriguez (1990). Irritant dermatitis was induced on the right ear by topical application of $0.01 \%$ TPA or capsaicin $(12.5 \mathrm{mg} / \mathrm{mL})$ both dissolved in acetone. The left ear (control) received the vehicle (acetone). The BPF was orally administrated at $13 \mathrm{~mL} / \mathrm{kg}, 26 \mathrm{~mL} / \mathrm{kg}$ or 52 $\mathrm{mL} / \mathrm{kg}$, (the dose of $26 \mathrm{~mL} / \mathrm{kg}$ was related with that used by the popular users) and dexamethasone (DEXA) was intraperitoneally (i.p.) administrated at $2 \mathrm{mg} / \mathrm{kg}$ one hour before applications of the irritant agents. Animals were killed by cervical dislocation at six hours (TPA) or one hour (capsaicin) after the induction of inflammation. An 8-mm diameter punch biopsy was performed on each ear. The percentage of edema inhibition was calculated as follows: the weight of the untreated ear (control) was subtracted from the treated ear for each group. The mean irritant edema was obtained by subtracting the average vehicle control ear weight from the average TPA-treated or capsaicin ear weight. The percentage inhibition of edema was calculated by subtraction of average vehicle edema value from the average of the BPF or DEXA. Edema value and the mean were divided by the average vehicle edema value. The resultant value was multiplied by 100 . These experiments were carried out 4 times with groups of five animals $(n=20)$.

\section{Carrageenan-induced rat paw edema}

Carrageenan-induced edema assay was carried out according to Winter et al. (1962). Edema was induced on the right hind foot of a rat by subplantar injection of $0.1 \mathrm{~mL}$ of a solution of $1 \%$ carrageenan in $0.9 \% \mathrm{NaCl}$ $(w / v)$. Foot Swelling of the carregeenan or contralateral saline injections was measured before injection the of carrageenan (time 0 ) and at 1.5 and 3 hours after injection of carrageenan. The control animal groups received indomethacin $(5 \mathrm{mg} / \mathrm{kg}$, oral administration), a reference anti-inflammatory substance, or vehicle (alcohol) under the same experimental conditions. The BPF animal groups received $13 \mathrm{~mL} / \mathrm{kg}, 26 \mathrm{~mL} / \mathrm{kg}$ or $52 \mathrm{~mL} / \mathrm{kg}$ one hour before carrageenan administration. The degree of paw edema was determined by measuring the hind paw volume by plethysmography (Ugo Basile, Italy). The edema inhibition was calculated for each animal group in comparison with its vehicle-treated group. Groups of five animals were used in each test. These experiments were carried out 4 times $(n=15)$.

\section{Statistical analysis}

Data were statistically analyzed by Bonferroni or Student's t-test using the software GraphPad Prism version 3.02. Data were expressed as mean \pm S.E.M. Differences between control (vehicle) and treated groups with $\mathrm{p}<0.05$ were considered statistically significant. 


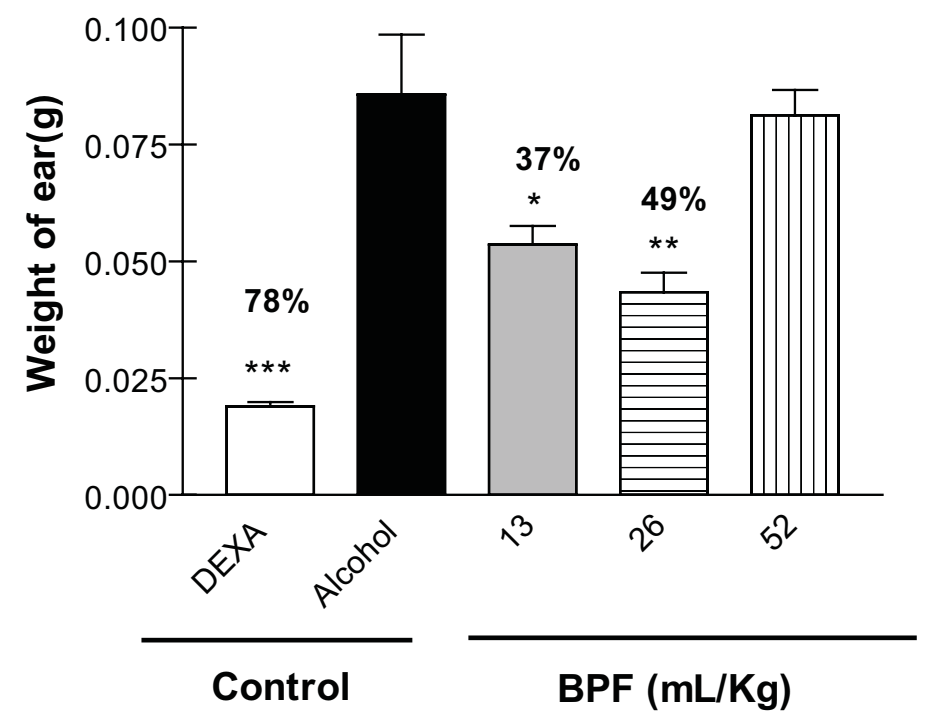

A

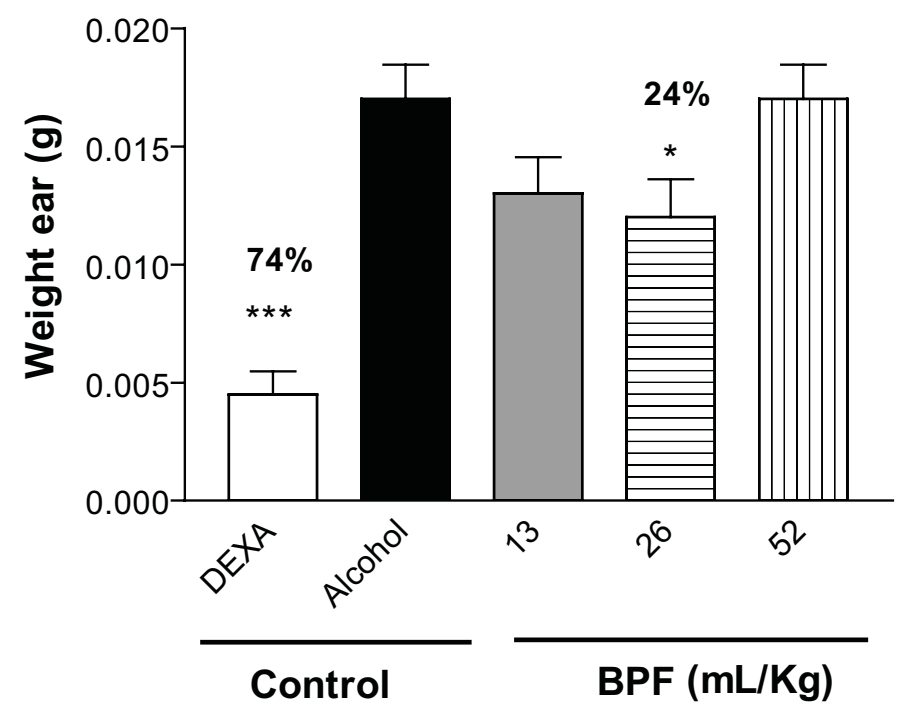

B

Figure 1. Effect of the BPF on TPA (A) or capsaicin (B)-induced mouse ear edema. Groups of mice $(\mathrm{n}=20)$ were treated p.o. with the indicated doses of BPF $(\mathrm{mL} / \mathrm{kg})$, alcohol (vehicle) or DEXA $60 \mathrm{~min}$. before the irritating agent's application. Animals were killed at six hours (TPA) or one hour (capsaicin) after the induction of inflammation. Punch biopsy was performed on each ear. The percentage of edema inhibition was calculated. Data were expressed as mean \pm S.E.M. Differences between control (alcohol) and treated groups with $* \mathrm{p}<0.05, * * \mathrm{p}<0.01, * * * \mathrm{p}<0.001$ were considered statistically significant. 
Table 1. Effect of the BPF on the carrageenan-induced paw edema.

\begin{tabular}{lccc}
\hline Treatments & \multicolumn{3}{c}{ Edema volume (mL) mean \pm S.E. } \\
& $1.5 \mathrm{~h}$ & $3 \mathrm{~h}$ & $5 \mathrm{~h}$ \\
\hline Alcohol & $0.483 \pm 0.026$ & $0.870 \pm 0.037$ & $0.880 \pm 0.035$ \\
Indomethacin & $0.287 \pm 0.025 \#$ & $0.530 \pm 0.028 \#$ & $0.540 \pm 0.030 \#$ \\
BPF 13 mg/mL (p.o) & $0.330 \pm 0.026 \#$ & $0.600 \pm 0.053 \#$ & $0.740 \pm 0.032$ \\
BPF 26 mg/mL (p.o) & $0.370 \pm 0.033^{*}$ & $0.700 \pm 0.050 *$ & $0.810 \pm 0.114$ \\
BPF 52 mg/mL (p.o) & $0.400 \pm 0.027 *$ & $0.750 \pm 0.036 *$ & $0.828 \pm 0.048$ \\
\hline
\end{tabular}

Groups of mice $(\mathrm{n}=15)$ were treated p.o. with the indicated doses of BPF ( $\mathrm{mL} / \mathrm{kg})$, alcohol (vehicle) or indomethacin $60 \mathrm{~min}$ before subplantar carrageenan injection. The change of footpad volume was determined at $1.5 ; 3$ and $5 \mathrm{~h}$ after phlogistic agent injection. Each value represents the mean \pm S.E.M. of 10-15 rats per group. Statistically significant data are related with the control group (alcohol) and expressed as * $p \leq 0.05$, $\# p \leq 0.001$ (unpaired Student's $t$-test).

\section{RESULTS}

Effect of the BPF treatment on TPA or capsaicininduced mouse ear edema

The results obtained on TPA-induced mouse ear edema are shown in Figure 1A. The treatment with BPF at doses of $13 \mathrm{~mL} / \mathrm{kg}$ or $26 \mathrm{~mL} / \mathrm{kg}$ inhibited the edema by 37 and $49 \%$, respectively. The mean of the weight of ear edema from the two treated groups was statically significant ( $p<0.05$ and $p<0.01$, respectively) as compared with the control group (vehicle). No inhibitory effect was observed at dose of $52 \mathrm{~mL} / \mathrm{kg}$ (Figure 1A). In the capsaicin-induced mouse ear edema test, the treatment with the BPF induced a significant inhibitory effect $(24 \%$, $\mathrm{p}<0.05$ ) only at the dose of $26 \mathrm{~mL} / \mathrm{kg}$ (Figure $1 \mathrm{~B}$ ). No inhibitory effect was observed at doses of $13 \mathrm{~mL} / \mathrm{kg}$ or 52 $\mathrm{mL} / \mathrm{kg}$ (Figure 1B). DEXA treatment showed inhibitory effect in both inflammatory experimental models (Fig $1 \mathrm{~A} / \mathrm{B})$.

Effect of the BPF treatment on the carrageenaninduced hind paw edema

The inhibitory effect of the BPF $(13,26$ or 52 $\mathrm{mL} / \mathrm{kg}$ ) on the carrageenan-induced hind paw edema was reached $1 \mathrm{~h}$ and $30 \mathrm{~min}$ after the phlogistic agent administration $(0.330 \pm 0.026 ; 0.370 \pm 0.033 ; 0.400 \pm$ 0.027 ; respectively) and it was maintained until $3 \mathrm{~h}(0.600$ $\pm 0.053 ; 0.700 \pm 0.0503 ; 0.750 \pm 0.036$; respectively) when compared with the control animal group - vehicle treated animals (Table 1). In the indomethacin-treated animals it was observed edema reduction at both time analyzed (Table 1).

\section{DISCUSSION}

The results obtained in this study confirm that BPF-treated mice presented a significant antiinflammatory effect. This effect is due to the presence of plants such as Eucalyptus globulus Labill, Peltodon radicans Pohl and Schinus terebinthifolius Radd that have this property.

In the peel of Schinus terebinthifolius Raddi was demonstrated the presence of tannins that have adstringent action, disinfectant and anti-inflammatory effects (Diniz et al., 1997) and anti- bacterial activity (Lima et al., 2006a,b). It was also showed the therapeutic action of the Schinus terebinthifolius Raddi in chronic inflammatory vagina colon (Diniz et al., 1997) and ulceration sore (Pormigoni; Carlini., 1990).The Peltodon radicans Pohl has antibacterial activity induced by the timol present in the essential oil of the plant (Diniz et al., 1997). Carriconde (1995) demonstrated an improvement in the pathologies related to respiratory airway.

Many species of the genus Eucalyptus (Myrtaceae) are used in Brazilian folk medicine for a variety of medical conditions. Monoterpenoids components present in the essential oils from Eucalyptus are commercially available for the treatment of the common cold and other symptoms of respiratory infections (Juergens et al., 1998a).

It was previously reported that the monoterpene components of the oils of Eucalyptus, such as eucalyptol, are potent inhibitors of the inflammatory mediators, such as pro-inflammatory cytokines (Juergens et al., 1998a). Furthermore, the production of leukotriene $\mathrm{B}_{2}$, prostaglandin $\mathrm{E}_{2}$, and other arachidonic acid metabolites in human monocytes were inhibited by eucalyptol (Juergens et al., 1998b). Essential oil extracts from the Eucalyptus species can be associated with antiinflammatory properties at least due to the presence of the above component (Silva et al, 2003).

The BPF inhibited the capsaicin-induced mouse ear edema. BPF- treated mice at dose of $26 \mathrm{~mL} / \mathrm{kg}$ showed $24 \%$ of ear edema inhibition as compared to the control group (alcohol). This dose is related to the one used in the folk medicine. In this experimental model, substance $\mathrm{P}$ (Santos; Calixto 1997; Otuki et al., 2001), tachykinin, 5hydroxytryptamine (5-HT), prostaglandins and histamine mediate the inflammatory response (Blazro; Gabor, 1994). The inhibitory effect of the BPF on capsaicin-induced 
ear edema suggests that the phytoherbal formulation is modulating such mediators.

On the TPA inflammatory model the BPF also inhibited significantly the ear edema. Inflammation induced by TPA can activate the protein kinase $\mathrm{C}$ in a similar manner as the endogenous diacylglycerol (Just et al., 1998) and activated the phospholipase A2 (Salvemini et al., 1996). Activation of the protein kinase $C$, a calciumdependent enzyme, induces degranulation of neutrophil (Helfman et al., 1982), platelet and mast cells (Heiman; Crews, 1985) and induces smooth muscle contraction (Andrew; Somlyo, 1994). Jain et al. (1995) isolated two components of Schinus terebinthifolius Raddi that inhibit selectively the phospholipase A2. Then it is reasonable to suggest that the BPF may inhibit the calcium intracellular levels by inhibiting the protein kinase $\mathrm{C}$ as well as the arachidonic acid formation.

Preliminary results obtained from carrageenan inflammatory model showed the BPF inhibited the paw edema until $3 \mathrm{~h}$ (early phase of edema) after the phlogistic agent was administrated. Several mediators are involved in the carrageenan inflammatory model. During the early phase of the carrageenan inflammatory response it is observed the release of histamine, 5-hydroxytryptamine (5-HT) and bradykinin and the late phase (5 hours) is correlated with the high production of prostaglandins, bradykinin, proteases (Di Rosa; Willoughby, 1971), local activation of neutrophil cells (Bougthton-Smith et al., 1993), activation of COX-2 and the generation of great amount of NO (Seibart et al., 1994). It was demonstrated that the Eucalyptus globulus reduced NO production induced by lipopolysaccharide (LPS) and interferongamma (IFN- $\gamma$ ) in the murine macrophage cell line J774A (Vigo et al., 2004). The BPF is modulating the carrageenan-induced inflammation. Further studies need to be carried out to identify the molecular mechanisms involved.

This study demonstrated that the Brazilian polyherbal formulation has anti-inflammatory effect. We demonstrated by different models of inflammation that the dose related with the popular use showed better effect. The results presented here scientifically validate the BPF as an anti-inflammatory vegetal product.

\section{REFERENCES}

Andrew P, Somlyo AV 1994. Signal transduction and regulation in smooth muscle. Nature 372: 231-236.

Blazro G, Gabor M 1994. Anti-edematous action of some $\mathrm{H}_{1-}$ receptor antagonists. Agents and Actions 42: 13-18.

Boughton-Smith NK, Deakin A, Follenfant RL, Whittle BJR, Garland LG 1993. Role of oxygen radicals and aracdonic acid metabolites in the reverse passive Arthus reaction and carrageenin paw edema in the rat. Brit J Pharmacol 110: 896-902.

Braga R 1953. Plantas do Nordeste-Especialmente do Ceará. Natal: Universitária Federal do Rio Grande do Norte.

Brandão MGL, Cosenza GP, Moreira RA, Monte-Mor RLM
2006. Medicinal plants and other botanical products from the Brazilian Official Pharmacopoeia. Rev Bras Farmacogn 16: 408-420.

Carriconde C 1995. Plantas Medicinais \& Plantas Alimentícias. Olinda: Universidade Federal Rural de Pernambuco.

Delorne RJ, Miolla H 1979. Pronto Socorro do Sertão - A Cura pelas plantas. Porto Alegre: Grofosul.

Di Rosa M, Willoughby DA 1971. Studies of mediators of the acute inflammatory response induced inrats in different sites by carrageenin and tpertine. Eur J Pharmacol 104: 15-29.

Diniz MFM, Oliveira RAG, Medeiros ACD, Malta JA 1997. Memento Fitoterápico - As plantas como alternativa terapêutica: aspectos populares e científicos. João Pessoa: Universidade Federal da Paraíba.

Grassmann J, Hippeli S, Dornisch K, Rohnert U, Beuscher N, Elstner EF 2000. Antioxidant properties of essential oils. Possible explanations for their anti-inflammatory effects. Arzneimittel-Forsch 50:135-9

Heiman AS Crews FT 1985. Caracterization of the effects of phorbol esters on rat mast cell secretion. J Imunnol 134: 548-555.

Helfman DM, Appelbaum BD, Volgler WR 1982. Phospholipidsensite $\mathrm{Ca}^{2+}$ - dependent protein kinase and its substrate in human neutrophilis. Biochem Biophys Res Co 111: 847.

http://www.aguarabelo.com.br/produtos, accessed on may 2003.

Jain MK, Yu BZ, Rogers JM, Smith AE, Boger ET, Ostrander RL, Rheingold AL 1995. Specific competitive inhibitor of secreted phospholipase $\mathrm{A}_{2}$ from berries of Schinus terebinthifolius. Phytochemistry 39: 537-547.

Juergens UR, Stober M, Vetter H 1998a. Inhibition of cytokine production and arachidonic acid metabolism by eucalyptol $(1,8$-cineole) in human blood monocytes in vitro. Eur J Med Res 3: 508-510.

Juergens UR, Stober M, Schmidt-Schilling L, Kleuver T, Vetter H 1998b. Antiinflammatory effects of eucalyptol (1,8cineole) in bronchial asthma: inhibition of arachidonic acid metabolism in human blood monocytes ex vivo. Eur J Med Res 3: 407-412.

Just MJ, Recio MC, Giner RM, Cuellar MJ, Manez S, Bilia AR, Rýos JL 1998. Anti-inflammatory activity of unusual lupane saponins from Bupleurum fruticescens. Planta Med 64: 404-407.

Lima MRF, de Souza Luna J, Dos Santos AF, de Andrade MC, Sant'Ana AE, Genet JP, Marquez B, Neuville L, Moreau N 2006a. Anti-bacterial activity of some Brazilian medicinal plants. J Ethnopharmacol 21:13747.

Lima MRF, Ximenes CPA, Luna JS, Sant'Ana AEG 2006b. The antibiotic activity of some Brazilian medicinal plants. Rev Bras Farmacogn 16: 300-306.

Lu XQ, Tang FD, Wang Y, Zhao T, Bian RL 2004 Effect of Eucalyptus globulus oil on lipopolysaccharideinduced chronic bronchitis and mucin hypersecretion in rats. Zhongguo Zhong Yao Za Zhi 29: 168-171.

Mantione CR, Rodriguez RA 1990. A bradykinin (BK1) receptor antagonist blocks capsaicin-induced ear inflammation mice. Brit J Pharmacol 99: 516-518.

Matos FJA 1999. Plantas da Medicina Popular do Nordeste: Propriedades Atribuidas e Confirmadas. Fortaleza: EUFC. 
Melo Junior EJM, Raposo MJ, Lisboa Neto JA, Diniz MFA, Marcelino Junior CAC, Sant'Ana AEG 2002. Medicinal plants in the healing of dry socket in rats: microbiological and microscopic analysis. Phytomedicine 9: 1109-1116.

Merlos MLA, Gómez M, Gira ML, Verticat J, García-Rafarell JF 1991. Effects of PAF-antagonists in mouse ear edema induced by several inflammatory agents. Brit $J$ Pharmacol 104: 990-994.

Otuki MF, Lima FV, Malheiros A, Cechinel-Filho V, Monache FD, Yunes RA, Calixto JB 2001. Evaluation of the antinociceptive action caused by ether fraction and a triterpene isolated from resin of Protium kleinii. Life Sci 69: 2225-2236.

Pormigoni MLO, Carlini EA 1990. Efeitos dos decoctos de Aroeira da Praia (Schinus terebinthifolius Raddi.) e da aroeira do sertão (Astronium urundeuva E.) sobre a úlcera experimental em ratos. X Simpósio de Plantas Medicinais do Brasil. Salvador, Brasil.

Rodrigues VE, Carvalho DA 2001. Levantamento etnobotânico de plantas medicinais no domínio do cerrado na região do alto Rio Grande - Minas Gerais. Ciênc Agrotec 25: 102-123.

Salvemini D, Wang Z, Wyatt PS 1996. Nitric oxide: A key mediator in the early and late phase of carrageenaninduced rat paw inflammation. Brit J Pharmacol 188: 829-898.

Santos ARS, Calixto JB 1997. Further evidence for the involvement of tachykinin receptor subtypes in formalin and capsaicin models of pain in mice. Neuropeptides 31: 381-389.

Seibart K, Zhang Y, Leahy K 1994. Pharmacological and biochemical demonstration of the role of cycloxygenase 2 in inflammation and pain. Proc Nat Acad Sci USA 91: 12013-12017.

Sherwin CM, Christiansen IJ, Duncan HWE, Lay JDC, Mench JA, O'Connor CE, Petherick JC 2003. Guidelines for the ethical use of animals in applied etiology studies. Appl Anim Behav Sci 8: 291-305.

Silva J, Abebeb W, Sousa SM, Duarte VG, Machado MIL, Matos FJA 2003. Analgesic and anti-inflammatory effects of essential oils of Eucalyptus. J Ethnopharmacol 89: 277-283.

Tavares JP, Martins IL, Vieira AS, Lima FAV, Bezerra FAF, Moraes MO, Moraes MEA 2006. Estudo de toxicologia clínica de um fitoterápico a base de associações de plantas, mel e própolis. Rev Bras Farmacogn 16: 350356.

Vigo E, Cepeda A, Gualillo O, Perez-Fernandez R 2004. Invitro anti-inflammatory effect of Eucalyptus globulus and Thymus vulgaris: nitric oxide inhibition in J774A murine macrophages. J Pharm Pharmacol 56: 257263.

Winter CA, Risley EA, Nuss GW 1962. Carrageenin-induced edema in hind a paw of the rats as an assay for antiinflammatory drug. Proc Soc Exp Biol Med 111: 544547. 